\title{
Augmented Reality-Based Mobile Education Game “Aku Suka Sayur” For Preschooler
}

\author{
V Vivianti* \\ Information Technology Education \\ Universitas Teknologi Yogyakarta \\ Yogyakarta, Indonesia \\ vivianti@uty.ac.id
}

\author{
Dwi Ratnawati \\ Information Technology Education \\ Universitas Teknologi Yogyakarta \\ Yogyakarta, Indonesia \\ dwiratnawati@uty.ac.id
}

\begin{abstract}
In the field of education, the use of educational mobile applications is becoming prevalent. This research explores the perception of parents and children on the use of the educational mobile application with Augmented Reality technology for preschoolers to learn vegetables. This present study is a part of research on the development $(R \& D)$ of the educational game "Aku Suka Sayur". This study is included in the process of product testing using the qualitative method. Observation and interviews are used as data collection tools. This educational game offers several features for recognizing vegetable names, guessing vegetable pictures, singing the song "Aku Suka Sayur", and AR features for coloring vegetable pictures. Children can do coloring activities on paper with vegetable images then the image is scanned using the application on the AR menu. Observation conducted had found that both children and parents have overall positive attitudes towards the use of AR application "Aku Suka Sayur". This study found that children feel happy and enthusiastic about playing games so that the learning process becomes more interesting and less boring. Despite the potential offered by AR technology, few works explore the potential of $A R$ to support learning with the interactive feature of live coloring, especially for preschool children. Therefore, parents and educators can play an active role in implementing this technology in their learning.
\end{abstract}

Keywords - Augmented Reality, Educational Mobile Game, Preschooler

\section{INTRODUCTION}

Vegetables are an important component of a balanced and safe ready-to-eat form) vegetables seem to be an important diet, and evidence supports a positive correlation between higher vegetable intake in schools and health benefits determinants for rising vegetable intake [1]. Furthermore, evidence indicates that the suggested consumption of vegetables remains that parents play a crucial role in promoting and endorsing not reached in many countries [2]. During the first years of a person's life, the consumption of vegetables is very significant. Their sufficient intake was linked to a healthy weight in infancy $[3,4]$. Secondly, during adolescence, healthy eating habits acquired appear to continue into adulthood [5,6,7]. First and foremost, the duty of feeding children nutritious food and vegetables is the responsibility of parents' obligation and what kinds of meals children get at home is outstanding. Nutritious and balanced food is essential for children especially preschooler's growth. The nutritional content of each food menu needs to be considered due to a lot of children's physical activities. Vegetables are high in nutrients and very important for children's growth, yet unfortunately, children tend to dislike vegetables [8].
Consuming vegetables for children need to be improved by introducing vegetables to children. Several interventions have been carried out to better understand what improves the consumption of vegetables by children under 5 years of age $[9,10]$. In childcare settings, however, interventions focusing on growing vegetable intake among children are minimal. Moreover, health education for preschoolers rarely attracts children to like vegetables. The writers here try to take another intervention on how parents and teachers can deliver the learning experience for their children about the importance of vegetables through technology integration. Besides, integrating technology is possibly carried out to build children's interest.

Technology is ubiquitous in the various field nowadays. One of the technology tools massively used is Augmented Reality. AR is being used in almost every field including Architecture, Engineering, Construction Industry [11], dan Entertainment [12]. In education, Augmented Reality is one of the emerging technologies which has very huge potential [13]. Application of Augmented Reality (AR) now is available extensively to support cognitive development and education for preschoolers. The application of AR with educational features offers an interesting and unique learning experience by obscuring the boundary between the real world where the children live and the virtual world in which they see on the screen [14]. In all kinds of environments, virtual reality is popping out these days. Recently, the application of AR to children, especially preschoolers, has also been used. It allows preschoolers to engage with the material and learn faster. It's a really good idea because kids learn by imagination. A study conducted on the application of AR technology in early childhood classrooms in Malaysia shows that it is effective in maintaining a high level of motivation and engagement among preschool children [15]. Also, the study on the AR application in Spain shows that children learning outcomes improved after AR was implemented in the teaching-learning process. From those two previous studies, it can be implied that the use of AR technology provides a positive alternative for children to experience engaging and motivating learning [16].

With the advent of AR recently, technology has attracted the attention of researchers and educators as a fascinating alternative and exciting way to build teaching and learning resources. Nonetheless, very few have discussed its use in the study of vegetables. This study is advanced research on the development of the educational game "Aku Suka Sayur". This educational game offers several features: recognizing vegetable names, guessing vegetable pictures, singing the song "Aku Suka Sayur", and AR features for coloring 
vegetable pictures. Children can do coloring activities on paper with vegetable images then the image is scanned using the application on the AR menu. The scan results are vegetable objects in 3D on the smartphone screen. This paper describes the implementation of AR to introduce kinds of vegetables for preschoolers. Moreover, this study tries to give an alternative to technology implementation especially live coloring with Augmented Reality.

\section{METHODS}

This research is part of research for growth. Need analysis, product specification recognition, product creation, validation, revision, and product testing are the development techniques used. This study is included in the process of product testing. This study employed a descriptive qualitative method. The writers analyze the collected data in the form of words, pictures and not in numbers [17]. This study was mainly concern with the responses of using Augmented Reality based educational mobile game for preschoolers.

This study was conducted in July 2020 at the writers' residence with the target of children aged 3 to 5 years. The number of participants in this qualitative study was not determined by the size of the participants using statistical techniques, but it only determined the approximate number of samples with heterogeneous sample types on 6-12 informants $[18,19]$.

There were 8 preschoolers as respondents assisted by parents as informants in this study. The object of this research is a mobile educational game "Aku Suka Sayur" using Augmented Reality technology. Video-recording observation is used to investigate the interaction of young children with this AR application. The observation was used as a data collection tool because the children are not proficient in reading and writing yet. Besides, the basic interview is carried out to ask parents to rate how they feel about using the AR application "Aku Suka Sayur" during accompanying their children learning.

\section{RESULT AND DISCUSSION}

The findings and discussion will be presented in 3 categories. The first point is the description of the Educational Game "Aku Suka Sayur". The second point is children's responses to this game. The third point is parents' responses after using this application.

\section{A. Educational Game "Aku Suka Sayur”}

The object of this research is an Augmented Reality based educational mobile game for pre-schoolers. This educational game consists of several main menus, namely: identifying veggie names, guessing veggie names, slinging veggie songs, and live coloring using AR.

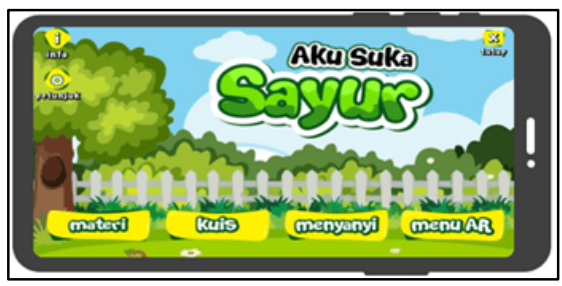

Fig. 1. Main Menu

\section{Identifying Veggie Names}

This menu is displayed to introduce veggie name and shape. Users can see veggie pictures accompanied by sound to mention veggie name when children (user) click the picture displayed on the screen.

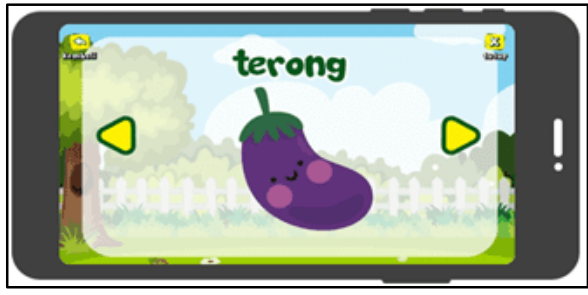

Fig. 2. Identifying Veggie Names

\section{Guessing Veggie}

There are some veggies displayed on this page, then the question "Yang manakah gambar kubis?" (which picture is cabbage?) followed. Children must choose the picture among the options provided. Feedback will be shown up after children answer the question for both correct and incorrect answers.

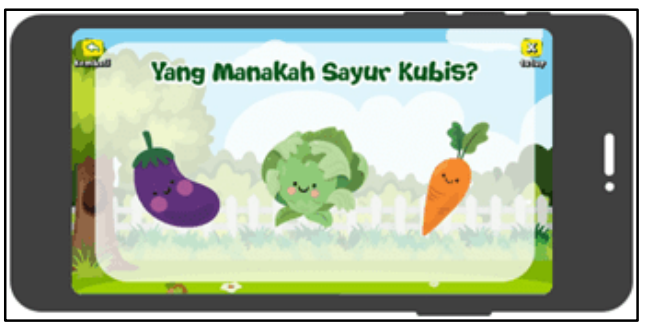

Fig. 3. Guessing Veggie

\section{Singing a song "Aku Suka Sayur”}

Children can sing the song "Aku Suka Sayur" on this page. This song will be played along with the animation. Through singing a song it is hoped that children will start to like veggie.

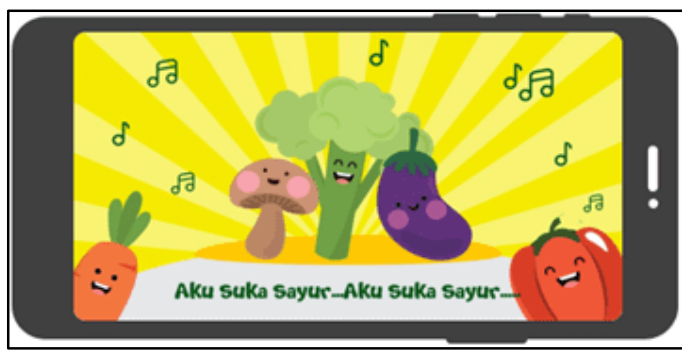

Fig. 4. Singing a song "Aku Suka Sayur"

\section{Live coloring with AR features}

This menu is the core of this application which is supported by Augmented Reality. This application is 
accompanied by a coloring worksheet. Children's work can be scanned using an Android mobile phone in this application. After it is scanned, there will be a 3D form of the children's coloring worksheet.

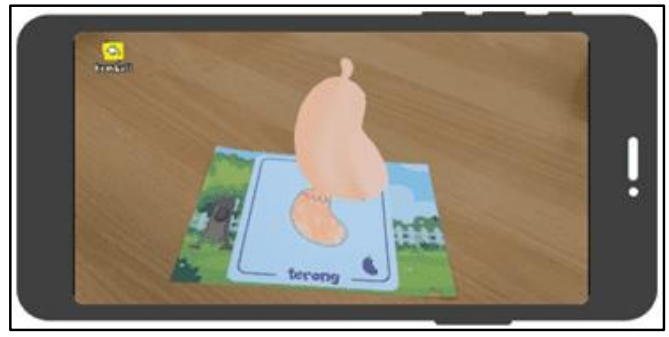

Fig. 5. Live coloring with AR features

\section{B. Users Responses on Educational Game "Aku Suka Sayur"}

Respondents in this study were 8 preschoolers and 8 parents. The preschoolers consisted of 2 boys and 6 girls aged 3 to 5 years. The videotaped observation and field notes indicated that all children enjoyed the AR-based learning activity "Aku Suka Sayur". They gave positive and enthusiastic responses. Children's responses toward the use of this application are discussed in the following description.

Student A opened a package of educational games consisting of games installed on smartphones, coloring worksheets, and color markers. Her eyes sparkled and she rushed to do coloring. She opened the application and tried various features, "Whoaaa, the eggplant can come out of the cellphone". She was getting excited about coloring other worksheets and trying them out.

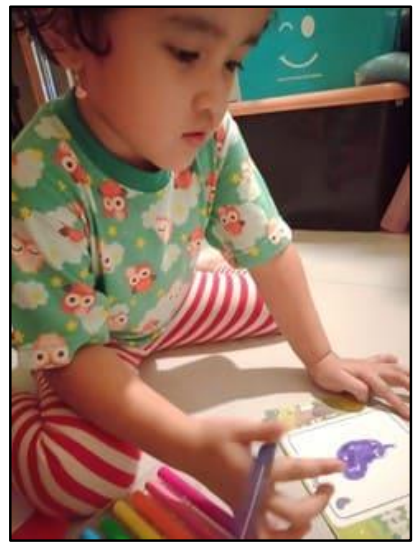

Fig. 6. Student A was coloring the worksheet

Student B was amazed by the vegetable pictures displaying on the application. Initially, she could not distinguish between tomatoes and carrots. She made mistakes repeatedly, but after several times repeating the identifying veggie names menu, finally, she could tell the differences. She was very enthusiastic about coloring pictures. As we documented, she even asked to be photographed posing with a vegetable worksheet.

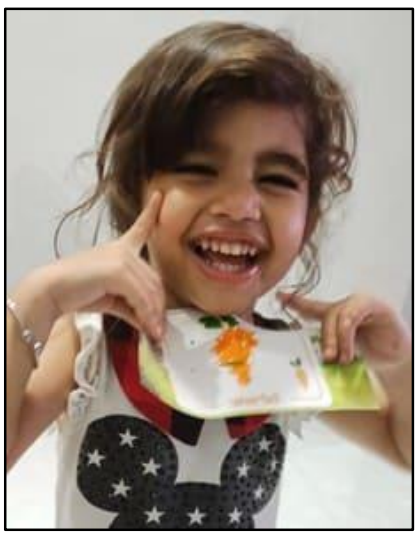

Fig. 7. Student B's photo holding the worksheet

Student C liked the song "Aku Suka Sayur". She could memorize songs instantly. Suddenly she got into a chair and sang it cheerfully while dancing.

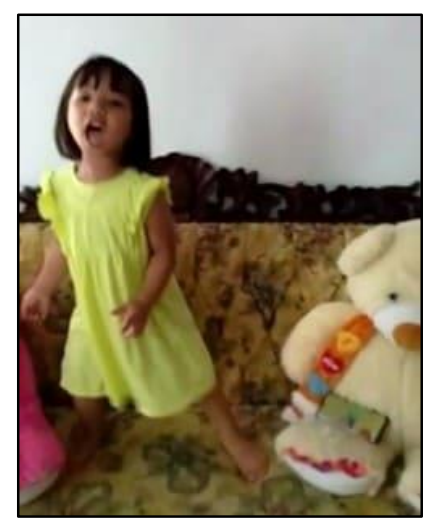

Fig. 8. Student C was singing "Aku Suka Sayur"

Student D liked the Augmented Reality menu. She asked for additional worksheets to try out different colors. She was amazed when she saw that the vegetable object that was scanned with the application had its color change according to her color on the worksheet.

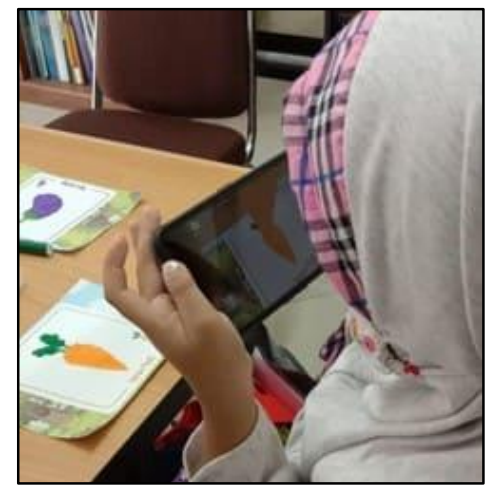

Fig. 9. Student $\mathrm{D}$ was playing with AR features 
Student E opened the application and she shouted excitedly finding colorful objects. Her favorite part is the song, so she played the song repeatedly. Indirectly this educational game boosts the children to love veggies. Her mother told us that she does not like broccoli very much. Surprisingly after she played the application, she asked her mom to cook broccoli.

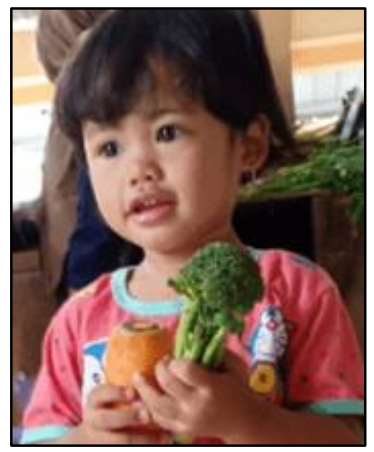

Fig. 10. Student E was holding carrot and broccoli

Live coloring became Student F's favorite part of learning using this media. She played the game "Aku Suka Sayur" until she could name the vegetables correctly. She colored the worksheet and named the vegetables.

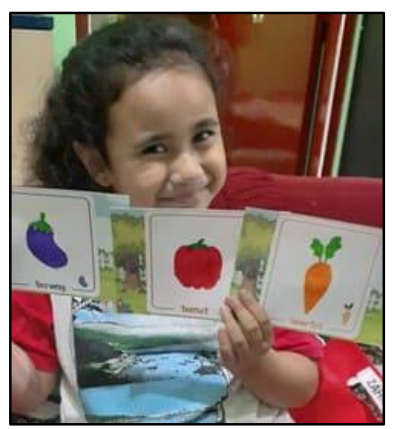

Fig. 11. Student F's coloring worksheet

As the program is operated, student $\mathrm{G}$ danced following the song "Aku Suka Sayur". When he played the games, he felt enthusiastic in identifying the veggie name. He was also able to mention veggie names correctly".

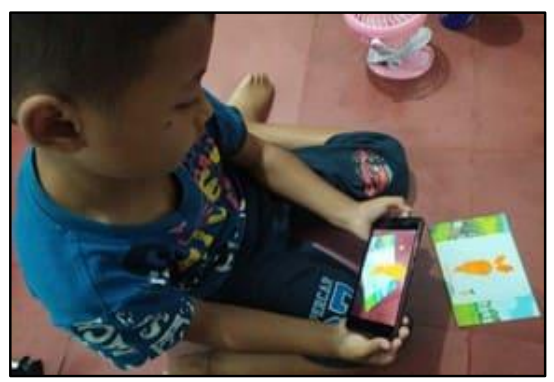

Fig. 12. Student $\mathrm{G}$ was operating the application
When student $\mathrm{H}$ started to scan the picture, he expressed his interest by saying "Mama, terongnya lucu ya. Bisa gerak"( Mom, the eggplant is so cute. It can move). Then he tried to memorize veggie names by repeating the sound played on the screen.

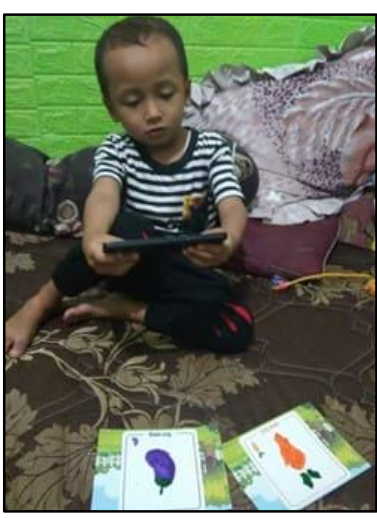

Fig. 13. Student $H$ was playing with $A R$ features

\section{Parents' Response on the use of AR Application}

$\mathrm{AR}$ is a brand-new application experience for both children and their parents. All respondents showed positive attitudes towards AR-based educational game as well as their concerns about their integration for teaching preschoolers. Preschoolers' parents believed it was an interesting experience to have AR for their children learning. The following excerpts from transcripts of the interviews illustrate parents' positive attitudes:

"This application is really helpful in assisting children in interestingly learning veggie. (Student F's mom)"

"It is so helpful for children learning veggie with this application. She sings the song "Aku Suka Sayur" every day. (Student C's Mom)"

\begin{abstract}
"My son expresses his interest in learning using this media. He tends to remember the acquired vocabulary from this educational game. The use of "Aku Suka Sayur" media involves family members in creating a positive learning experience. (Student H's Mom)"
\end{abstract}

The present study found that the AR-based educational game "Aku Suka Sayur" had promoted excitement, engagement, and enjoyment in the participating pre-schoolers. All the children enjoyed the activities very much. The ARbased learning activity has triggered their imagination and creativity. Their reactions to the AR-animated objects were different from those to seeing vegetables printed on a piece of paper. 
The observations showed that a well-designed Augmented Reality-based educational game application can support children's learning by attracting children's attention and encouraging them to learn in a fun way. Children are not fixated on seeing media activities, but children are also physically active so that they can involve several senses. This is following the opinion of experts that AR can contribute in many ways to support the teaching and learning process where the students' senses are involved in interactive activities using manipulative material [20]. Besides, self-learning is supported by fun edutainment in a user-friendly interface [21]. This is also in line with a study on designing and evaluating an AR alphabet book. The finding of their study shows that most students reacted positively towards the AR book and they like and enjoy using the AR book [22].

From the perspective of parents, Augmented Reality technology applied to the educational game "Aku Suka Sayur" can facilitate children's learning processes and increase children's motivation to know and like vegetables. As stated in previous studies that parents like AR technology because they find it useful, it facilitates the learning process and increases motivation, knowledge, reading and writing, creativity, and satisfaction levels. AR resources are suitable for various levels of education and not only in training for higher levels but also for preschoolers [23]. The result of this study supports the previous study findings carried out in Malaysia. They mention that parents have confidence in the use of EMA (Educational Mobile Application) with AR technology for early childhood education [24].

However, the respondents in particular parents also discussed the technical disadvantages of this AR application. Firstly, it might pose some negative influences on children's social development. All the preschoolers' parents (interviewees) emphasized that communication skills and language development were very crucial in the early years. They are distressed that their children might be more interested in playing with their gadgets than interacting with their parents or friends. Besides, when the writers asked them whether utilizing AR application could lead to insufficient communication with others or not, they hold the same position that their children's social development mainly depends on parents' guidance and how they organize the activities with this application. Moreover, they also suggested if there were some additional functions like voice recording into the system and more veggie names put in the application, it could be better. Despite the potential offered by AR technology, few works explore the potential of AR to support learning with an interactive feature of live coloring, especially for preschool children.

\section{CONCLUSION}

This study aimed to explore the children and parent's response to the use of AR technology in teaching vegetables to preschoolers. In its implementation, this game application gains positive responses from both preschoolers and parents. Children feel happy and enthusiastic about playing games so that the learning process becomes more interesting and interactive. Utilizing this application can be an engaging and attractive learning tools at home. This application has a positive impact on children, children become more familiar with the types of vegetables and interested in trying to eat vegetables. Since children in the 21 st century use mobile devices daily, educators should consider incorporating this technology into their teaching, starting with early childhood education. Hence, to optimize teaching and learning, resourceful educators should be able to find a way to combine these tools. To recognize problems in implementing AR in early childhood education, more studies should be conducted.

\section{ACKNOWLEDGMENT}

The researchers hereby express our sincerest gratitude to Direktorat Riset dan Pengabdian Masyarakat (DRPM), Direktorat Jenderal Penguatan Riset dan PengembanganKementrian Riset, Teknologi dan Pendidikan Tinggi (RISTEKDIKTI) for providing time and the grant for fulling this research project under Penelitian Dosen Pemula (PDP) category.

\section{REFERENCES}

[1] World Health Organization, Global status report on noncommunicable diseases 2014: Attaining the Nine Global Noncomunicable Diseases Targets; A Shared Responsibility. Geneva, Switzerland: World Health Organization, 2014.

[2] Micha, R., Khatibzadeh, S., Shi, P., Andrews, K. G., Engell, R. E., \& Mozaffarian, D. (2015). Global, regional and national consumption of major food groups in 1990 and 2010: a systematic analysis including 266 country-specific nutrition surveys worldwide. BMJ open, 5(9), e008705.

[3] Tohill, B. C., \& Joint, F. A. O., Dietary intake of fruit and vegetables and management of body weight [electronic resource]. World Health Organization, 2005.

[4] De Kroon, M. L., Renders, C. M., Van Wouwe, J. P., Van Buuren, S., \& Hirasing, R. A., The Terneuzen birth cohort: BMI changes between 2 and 6 years correlate strongest with adult overweight. PloS one, 5(2), 2010.

[5] Fletcher, S., Wright, C., Jones, A., Parkinson, K., \& Adamson, A. (2017). Tracking of toddler fruit and vegetable preferences to intake and adiposity later in childhood. Maternal \& child nutrition, 13(2), e12290.

[6] Lien, N., Lytle, L. A., \& Klepp, K. I., Stability in consumption of fruit, vegetables, and sugary foods in a cohort from age 14 to age 21. Preventive medicine, 33(3), pp. 217-226, 2001

[7] Rasmussen, M., Krølner, R., Klepp, K. I., Lytle, L., Brug, J., Bere, E., \& Due, P., Determinants of fruit and vegetable consumption among children and adolescents: a review of the literature. Part I: quantitative studies. International Journal of Behavioral Nutrition and Physical Activity, 3(1), 22, 2006.

[8] Elwarak, Ruhi, et al. "Perancangan Buku Pop-Up Mengenai Manfaat Buah dan Sayur Untuk Anak-anak." DEKAVE: Jurnal Desain Komunikasi Visual. Vol 8. No.1., pp. 1-19, 2018.

[9] Mikkelsen, M. V., Husby, S., Skov, L. R., \& Perez-Cueto, F. J., A systematic review of types of healthy eating interventions in preschools. Nutrition journal, 13(1), 56, 2014.

[10] Hodder, R. K., O'Brien, K. M., Tzelepis, F., Wyse, R. J., \& Wolfenden, L. (2020). Interventions for increasing fruit and vegetable consumption in children aged five years and under. Cochrane Database of Systematic Reviews, (5).

[11] Noghabaei, Mojtaba, et al. "Trend Analysis on Adoption of Virtual and Augmented Reality in the Architecture, Engineering, and Construction Industry." Data. 5.1, p. 26, 2020.

[12] Dow, Steven, et al. "Presence and engagement in an interactive drama." Proceedings of the SIGCHI conference on Human factors in computing systems. 2007.

[13] Redondo, Beatriz, et al. "Integration of augmented reality in the teaching of English as a foreign language in early childhood education." Early Childhood Education Journal. 48.2, pp.147$155,2020$.

[14] Oranç, Cansu, and Aylin C. Küntay. "Learning from the real and the virtual worlds: educational use of augmented reality in early childhood." International Journal of Child-Computer Interaction., 21, pp. 104-111, 2019.

[15] Rasalingam, R. R., Muniandy, B., \& Rass, R., Exploring the application of Augmented Reality technology in early childhood 
classroom in Malaysia. Journal of Research \& Method in Education (IOSR-JRME), 4(5), pp. 33-40, 2014.

[16] Cascales, A., Laguna, I., Pérez-López, D., Perona, P., \& Contero, M., An experience on natural sciences augmented reality contents for preschoolers. In International Conference on Virtual, Augmented and Mixed Reality. Springer, Berlin, Heidelberg, pp. 103-112, 2013

[17] Moleong, L.J. "Metodologi Penelitian Kualitatif Edisi Revisi". Bandung: PT. Remaja Rosdakarya, 2011.

[18] Herdiansyah, H. "Metode Penelitian Kualitatif untuk Ilmu-ilmu Sosial". Jakarta: Salemba Humanika, 2010.

[19] Afiyanti, Y.\& Rachmawati, I. N. Metodologi Penelitian Kualitatif Dalam Riset Keperawatan. Jakarta: Rajawali Press, 2014.

[20] Winkler T, Herczeg M, Kritzenberger H. "Mixed Reality Environments as Collaborative and Constructive Learning Spaces for Elementary School Children". Barker, P., Rebelsky S. (eds.)
Proceedings of World Conference on Educational Multimedia, Hypermedia and Telecommunications, pp. 1034-1039, 2001.

[21] Hsieh MC, Lee, JS. "AR Marker Capacity Increasing for Kindergarten English Learning". International Multi Conference of Engineers and Computer Scientists. vol. 1, pp. 663-666, 2008.

[22] Rambli, D. R. A., Matcha, W., \& Sulaiman, S. (2013). Fun learning with AR alphabet book for preschool children. Procedia computer science, 25, 211-219.

[23] Cascales, Antonia, David Clemente Pérez López, and Manuel Contero. "Study on Parents' Acceptance of the Augmented Reality Use for Preschool Education." Procedia Computer Science. 25, pp. 420-427, 2013.

[24] Shaharom, M. S. N., \& Halimb, M. A., Parents' Perception on the Use of Augmented Reality Educational Mobile Application for Early Childhood Education. Journal of Advanced Research in Social and Behavioural Sciences, 3(2), pp. 137-146, 2016. 